\title{
Factors affecting Zantedeschia Spreng. dedifferentiation in vitro
}

\author{
Vaida Jonytiené $\dot{x}^{*}$ \\ Ramunė Masienė, \\ Natalija Burbulis, \\ Aušra Blinstrubienè \\ Institute of Biology \\ and Plant Biotechnology \\ of Aleksandras Stulginskis University, \\ 11 Studentu St., Akademija 53361 \\ Kaunas district, Lithuania
}

Zantedeschia Spreng. is an economically important ornamental plant species. Improvement of aesthetic parameters and creation of novel variations of decorative plants are important economic goals for the commercial ornamental industry. The effect of the combination of growth regulators and the explant type on dedifferentiation induction in Zantedeschia aethiopica and Zantedeschia elliottianna was investigated. Research was carried out at the Institute of Biology and Plant Biotechnology of Aleksandras Stulginskis University and at the Laboratory of Agrobiotechnology of the Joint Research Centre in 2016-2017. Explants (leaf discs, spathe discs, and petiole segments) were cultured on the MS medium supplemented with different concentrations of indole-3-acetic acid (IAA), indole-3-butyric acid (IBA) and 6-benzylaminopurine (BAP), $30.0 \mathrm{~g} \mathrm{l}^{-1}$ sucrose, and $8.0 \mathrm{~g} \mathrm{l}^{-1}$ agar. Leaf discs and spathe discs did not show any response in the medium without growth regulators, while 16.3\% (Zantedeschia aethiopica) and $24.3 \%$ (Zantedeschia elliottianna) of isolated petiole segments formed callus. Our results showed that an appropriate combination of growth regulators for callus induction varied depending on the genetic background and the explant type. It was documented that isolated petiole segments of the arum lily and the calla lily induced more statistically reliable callus in a medium supplemented with combination BAP + IAA, while the combination BAP + IBA promoted callus formation from spathe disc tissues. Petiole segments manifested the highest dedifferentiation capability among the tested explant types. The results of the study showed that the ability of the somatic tissues of the arum lily and the calla lily to induce dedifferentiation seems to be a valuable material for improvement of ornamental values in these plants.

Keywords: Zantedeschia Spreng., explant type, callus induction, growth regulators

\section{INTRODUCTION}

Species of Zantedeschia Spreng. are very popular all over the world because of their attractive inflores-

\footnotetext{
* Corresponding author. Email: vaida.jonytiene@asu.lt
}

cence. They are commercially available as cut flowers and potted plants (Letty, 1973; Tjia, 1989; Corr, 1993; Kuehny, 2000). This plant is of high horticultural and economic value. Proper ambient temperature is necessary for the growth and development of the calla lily, so these plants are commonly grown 
in and exported from the countries in temperate zones with warm summers. Growing of the calla lily has been studied widely (Plummer et al., 1990; Corr, Widmer, 1991), the major efforts being focused on the control of flowering and tuber storage (Corr, Widmer, 1987, 1988). Commercially, multiplication of Zantedeschia Spreng. through branches and tubers is practiced to increase the size and the number of tubers. However, serious losses are caused by field-grown tubers infected by Erwinia soft rot (Chen et al., 2000). Due to high infection in individuals, Cohen (1981) and Ruiz (1996) with colleagues introduced plant propagation by an in vitro method. The in vitro technique has for long been elaborated commercially for the propagation of plant material for agricultural, horticultural, pharmaceutical, or research purposes, and for building up disease-free reserves (Thorpe, 2007).

Induction of dedifferentiation is regulated by endogenous and exogenous growth regulators in the plant nutrient medium (MS) (Murashige, Skoog, 1962). An important role in dedifferentiation induction is played by the type and concentration of plant growth regulators and their interaction (Khanam et al., 2000). It has been found that different combinations of auxins and cytokinins in the medium affected the intensity of callus formation (Makunga et al., 2005). For the induction of dedifferentiation of Zantedeschia Spreng., cytokinins are commonly used for explants (D’Arth et al., 2002; Naor et al., 2004; Yip et al., 2006). Indirect organogenesis offers devices for dedifferentiating plant tissue into callus permitting transformation and selection protocols, and regenerating processes of a whole plant in vitro from transformed callus (Robinson, Firoozabady, 1993). Various types of explants, such as rhizomes and buds (Chang et al., 2003; Ebrahim, 2004; Yip et al., 2006), shoots (Cohen, 1981), and leaves (Gong Xue-Qin et al., 2008; Zheng, 2010) have been used for dedifferentiation of the calla lily.

The aim of the current study was to establish a suitable system for optimal induction of callus from in vitro cultured leaf discs, spathe discs, and petiole segments of the arum lily and the calla lily, which could build the basis for ge- netic improvement of Zantedeschia Spreng. and aid in the multiplication and conservation of the resources of the wild calla lily.

\section{MATERIALS AND METHODS}

The experiment was carried out in 2016-2017, at the Institute of Biology and Plant Biotechnology of Aleksandras Stulginskis University and the Laboratory of Agrobiotechnology of the Joint Research Centre. Two species of Zantedeschia Spreng. were used: Zantedeschia aethiopica - the arum lily and Zantedeschia elliottianna - the calla lily. Leaf discs, spathe discs, and petiole segments were surface sterilized in $70 \%$ ethanol for $0.5 \mathrm{~min}$, then in $10 \%$ sodium hypochlorite for $4 \mathrm{~min}$, and rinsed three times for 5 min with sterile distilled water. The explants were placed on the MS medium supplemented with different concentrations and combinations of growth regulators. Firstly, for best callus initiation, two different cytokinins were tested: 6-benzylaminopurine (BAP) $\left(1.0 ; 2.0 \mathrm{mg} \mathrm{l}^{-1}\right)$ and kinetin (KIN) $\left(1.0 ; 2.0 \mathrm{mg} \mathrm{l}^{-1}\right)$. At a later stage of research, additional concentrations of auxins - indole-3-acetic acid (IAA) (0.25; $\left.0.5 ; 1.0 ; 2.0 \mathrm{mg} \mathrm{l}^{-1}\right)$ and indole-3-butyric acid (IBA) $\left(0.25 ; 0.5 ; 1.0 ; 2.0 \mathrm{mgl}^{-1}\right)$ - were added to the MS medium with $2.0 \mathrm{BAP}_{\mathrm{mg}} \mathrm{l}^{-1}$. The medium was supplemented with $30.0 \mathrm{~g} \mathrm{l}^{-1}$ sucrose and solidified with $8.0 \mathrm{~g} \mathrm{l}^{-1}$ agar. The medium was adjusted to $\mathrm{pH} 5.5$ prior to autoclaving at $115^{\circ} \mathrm{C}$ for $30 \mathrm{~min}$. For the above experiments, nine explants were cultured in Petri dishes, each containing $15 \mathrm{ml}$ of the medium. Petri dishes were sealed with Parafilm and maintained in a growth chamber at $22 \pm 2^{\circ} \mathrm{C}$, at a light density of $50 \mu \mathrm{mol} \mathrm{m} \mathrm{m}^{-2} \mathrm{~s}^{-1}$, photoperiod 16/8 h (day/ night).

The experiment was set up in a completely randomized design. Each treatment consisted of three replicate plates and the experiments were repeated three times. The percentage of explants producing callus was recorded [(number of explants with callus/total number of explants $) \times 100 \%$ ]. Computer programs STAT and ANOVA from SELEKCIJA and IRRISTAT (Tarakanovas, Raudonius, 2003) were used for 
calculation. The mean value and the standard error for each species were calculated based on the number of independent replications.

Means within a column followed by the same letter are not significantly different. The data are grouped by Duncan's multiple-range test $(P \leq 0.05)$.

\section{RESULTS AND DISCUSSION}

Scientists now count about 200 different kinds of natural and synthetic cytokinins. BAP is a synthetic cytokinin known for its high activity (Werner et al., 2003; Sakakibara, 2006). Cytokinin stimulates cell division, shoot and bud formation, and promotes chlorophyll synthesis (Werner et al., 2003). Different plant tissues have different dedifferentiation options (Coleman et al., 2003).

Callus formation frequency depends on the concentration of cytokinin BAP supplemented in the nutrient medium and on the type of Zantedeschia Spreng. explant. It was found that leaf and spathe explants of the arum lily and the calla lily did not form callus in the nutrient medium without growth regulators (Fig. 1). It was determined that 2.0 BAP $\mathrm{mg} \mathrm{l}^{-1}$ was the most efficient: this optimal concentration developed an average of $58.4 \%$ of callus formation in leaf explants of the arum lily. The dedifferentiation rate of growing leaf explants of the calla lily in the same medium was $44.7 \%$. Cultivation of isolated tissues of spathe of the arum lily on the medium supplemented with $1.0 \mathrm{mg} \mathrm{l}^{-1}$ BAP produced better results: these explants formed callus 1.2 times more intensively than the explants of the calla lily. The medium supplemented with $2.0 \mathrm{mg} \mathrm{l}^{-1}$ BAP spathe explants formed callus at $79.6 \%$ frequency for the calla lily and $62.6 \%$ for the arum lily.

The research results show that isolated petiole segments on the nutrient medium supplemented with the same concentrations of cytokinin produced better results: the tissue culture formed callus even on the medium without growth regulators $(16.3 \%$ - the arum lily and $24.3 \%$ - the calla lily). Isolated petiole explants formed callus in both kinds of plants it also depends on the composition of the nutrient medium. Better results were obtained by the arum lily.

The literature suggests that callus induction in isolated leaf tissue culture of Zantedeschia Spreng. was weak. Zheng (2010) established that the most active callus induction from leaf segments depends on the combination of

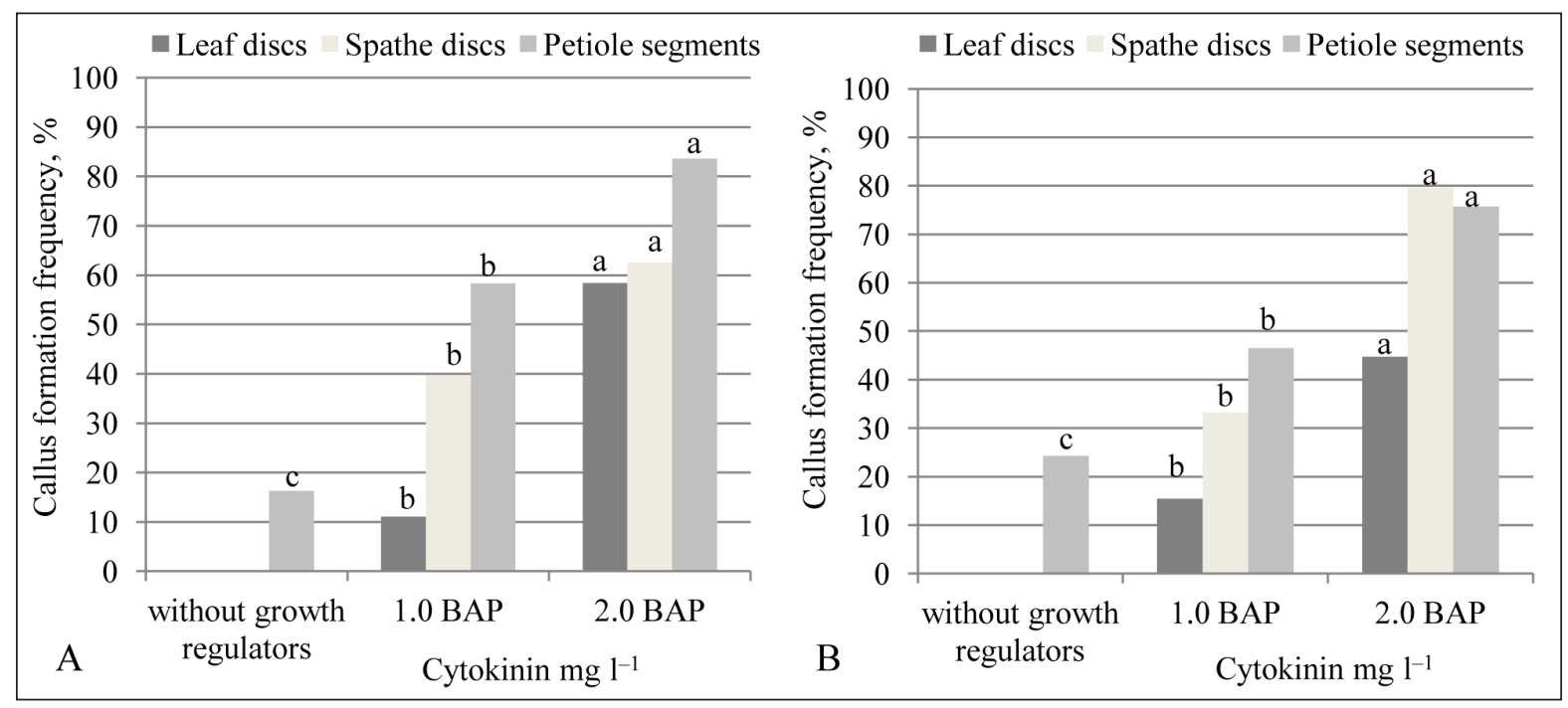

Fig. 1. Effect of cytokinins on the frequency of callus formation in different type of explants of the arum lily (A) and the calla lily (B)

Note: means not sharing a common letter (a, b...) are significantly different $P \leq 0.05$ 
the medium supplemented with growth regulators $0.1 \mathrm{mg} \mathrm{l}^{-1} \mathrm{NAA}+2.0 \mathrm{ml} \mathrm{l}^{-1}$ BAP. Gong with his team (2008) and Duquenne (2006) found that the best dedifferentiation was in the combination of the medium supplemented with growth regulators $2.0 \mathrm{mg} \mathrm{l}^{-1} \mathrm{NAA}+2.0 \mathrm{mg} \mathrm{l}^{-1} \mathrm{BAP}$.

At a later stage of our research, additional concentrations of auxins (IAA, IBA) were added to the MS medium with 2.0 BAP $\mathrm{mg} \mathrm{l}^{-1}$, which in some cases increased callus formation. It was found that the frequency of callus formation of arum lily leaf segments culture was the most intensive: $81.6 \%$ of explants cultivated on the MS medium supplemented with $0.5 \mathrm{mg} \mathrm{l}^{-1} \mathrm{IAA}+2.0 \mathrm{mg} \mathrm{l}^{-1} \mathrm{BAP}$ of growth regulators (Fig. 2). The other tested concentrations of IAA in the medium had a positive effect on the formation of callus.

The highest callus formation rate (85.2\%) was determined in isolated spathe discs of the arum lily, cultivated in the medium supplemented with $2.0 \mathrm{mg} \mathrm{l}^{-1} \mathrm{IAA}+2.0 \mathrm{mg} \mathrm{l}^{-1} \mathrm{BAP}$. In the medium supplemented with $0.5 \mathrm{mg} \mathrm{l}^{-1} \mathrm{IAA}+2.0 \mathrm{mg} \mathrm{l}^{-1}$ $\mathrm{BAP}$ and $1.0 \mathrm{mg} \mathrm{l}^{-1} \mathrm{IAA}+2.0 \mathrm{mg} \mathrm{l}^{-1} \mathrm{BAP}$ concentrations, callus formation rates were $61.6 \%$ and $63.8 \%$, respectively. The best callus formation frequency, $70.2 \%$, was influenced by $0.5 \mathrm{mg} \mathrm{l}^{-1}$ $\mathrm{IBA}+2.0 \mathrm{mg} \mathrm{l}^{-1} \mathrm{BAP}$.
The investigation showed that isolated arum lily petiole segments grown on the nutrient medium supplemented with IAA dedifferentiated intensively. The best supplement for callus formation from petiole explants was $1.0 \mathrm{mg} \mathrm{l}^{-1}$ IAA concentration: the frequency of callus formation was $96.5 \%$. Both kinds of isolated leaf culture of the investigated plants were unable to form callus on the medium without growth regulators.

In vitro studies of spathe explants are quite rare. Studies on callus induction from that type of isolated tissues are often applied to Anthurium (Anthurium), which is assigned to the Araceae family, the same as the arum and calla lilies. Budiarto (2008) studied dedifferentiation of explants and found that the nutrient medium is appropriate to supplement the BAP in combinations with auxins.

Isolated leaf discs of the calla lily in the nutrient medium supplemented with $0.25 \mathrm{mg} \mathrm{l}^{-1}$ $\mathrm{IAA}+2.0 \mathrm{mgl}^{-1} \mathrm{BAP}$ and $0.5 \mathrm{mg} \mathrm{l}^{-1} \mathrm{IAA}+2.0 \mathrm{mg}$ $\mathrm{l}^{-1}$ BAP combinations formed callus at the frequency of $51.4 \%$ and $55 \%$, respectively (Fig. 3). Increasing the concentration of auxin in the medium to 1.0 and $2.0 \mathrm{mg} \mathrm{l}^{-1}$, the frequency of callus formation increased to $66.7 \%$ and $64.8 \%$. The differences were insignificant.

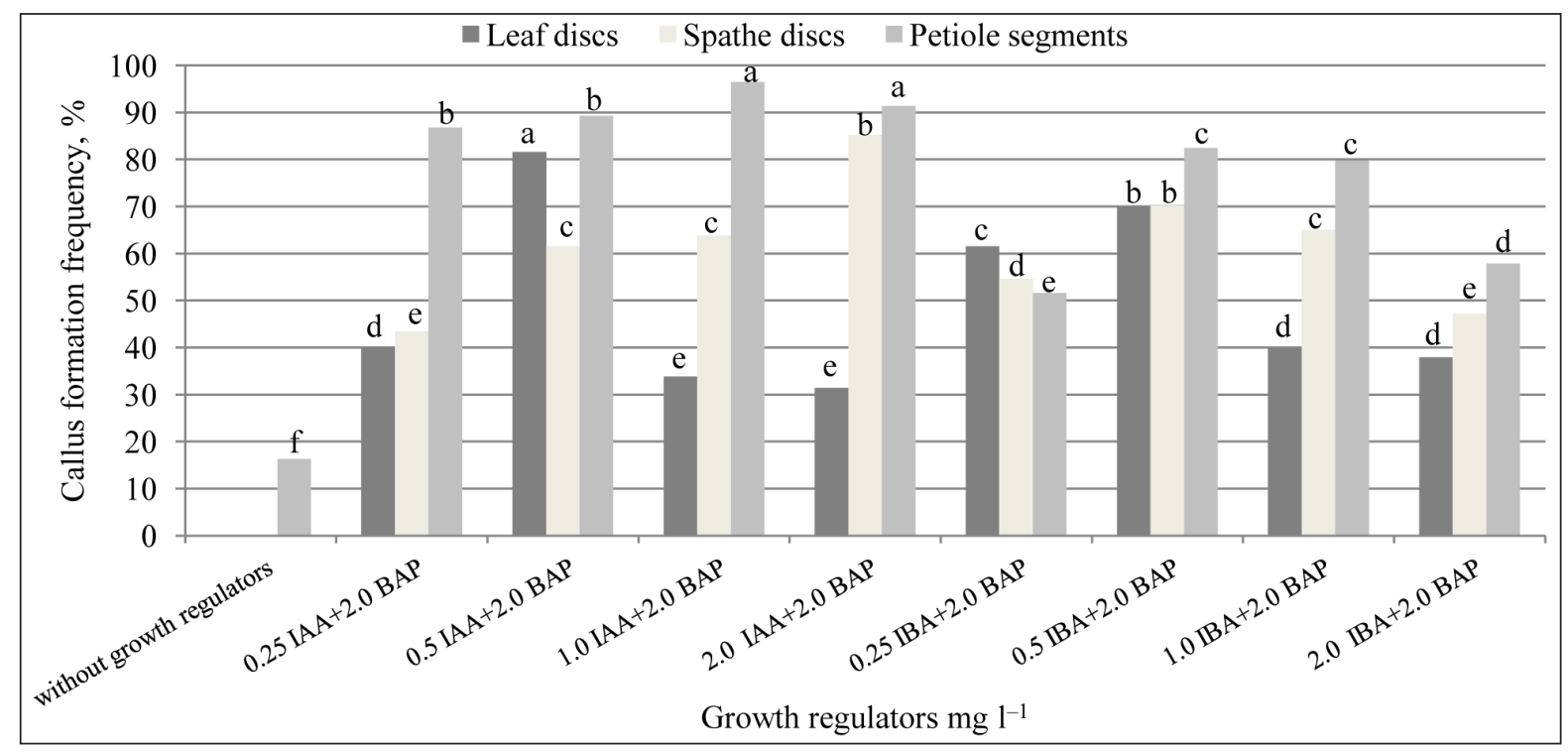

Fig. 2. Effect of growth regulators and the type of explants on the frequency of callus formation from arum lily Note: means not sharing a common letter (a, b...) are significantly different $P \leq 0.05$ 


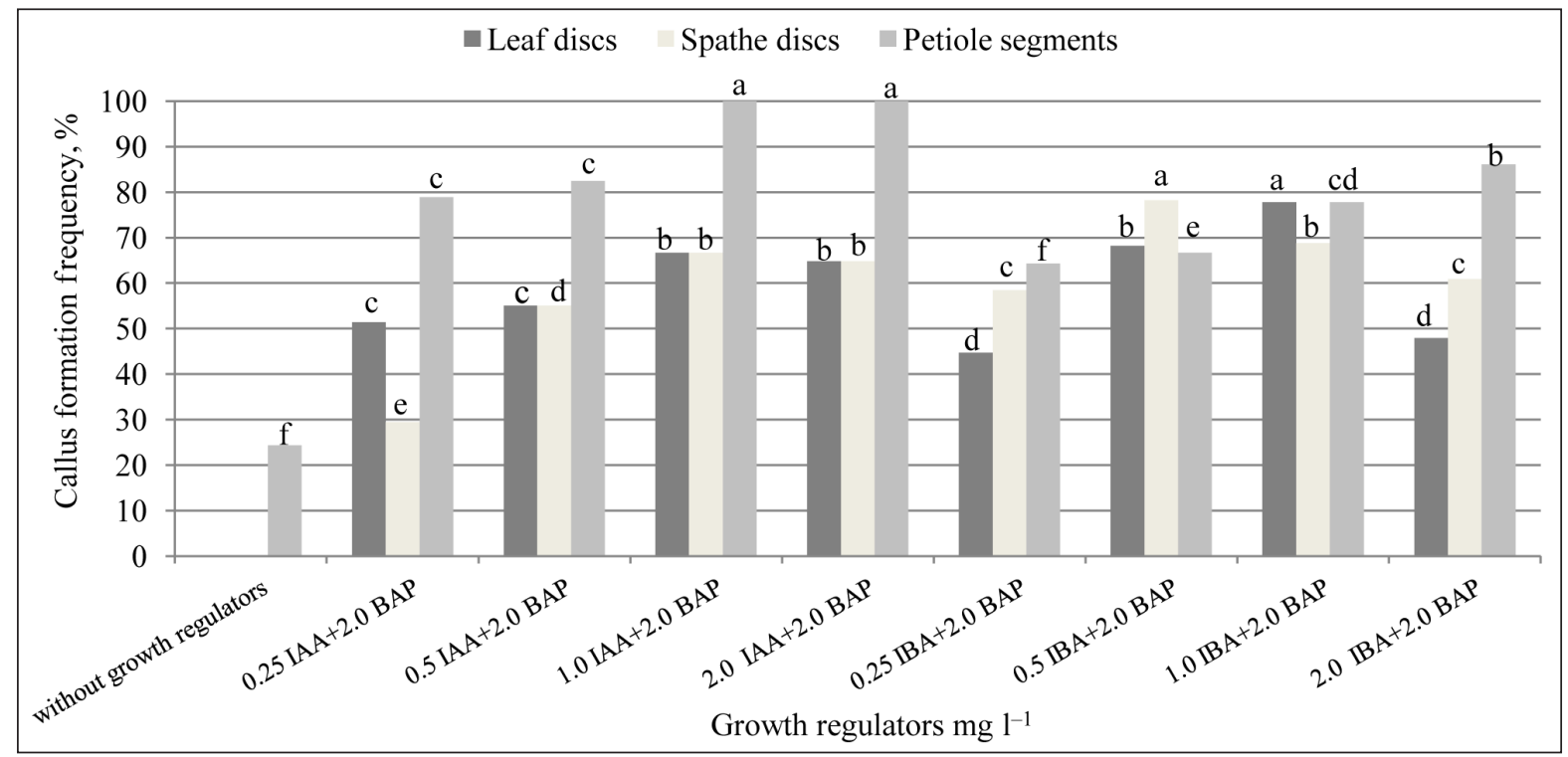

Fig. 3. Effect of growth regulators and the type of explants on callus formation frequency from the calla lily Note: means not sharing a common letter (a, b...) are significantly different $P \leq 0.05$

It was determined in the investigation that growing leaf explants of the calla lily on the medium with increasing concentration of the IBA in combination with BAP the frequency of callus formation increased significantly. The medium supplemented with $1.0 \mathrm{mg} \mathrm{l}^{-1}$ IBA in combination with $2.0 \mathrm{mg} \mathrm{l}^{-1}$ BAP produced the highest callus formation rate of $77.8 \%$.

The average results of this study showed that the spathe discs of the calla lily formed callus less frequently than the explants of the arum lily. Evaluation of the effect of IBA on the genesis of spathe callus of the calla lily showed that explants formed callus intensively. The best result $-78.2 \%$ - of the callus formation rate with calla lily spathe discs was determined in the medium supplemented with $0.5 \mathrm{mg} \mathrm{l}^{-1}$ $\mathrm{IBA}+2.0 \mathrm{mg} \mathrm{l}^{-1} \mathrm{BAP}$ additive. Increasing concentrations of IBA from $1.0 \mathrm{mg} \mathrm{l}^{-1}$ to $2.0 \mathrm{mg} \mathrm{l}^{-1}$ in the medium inhibited the process of dedifferentiation.

Both types of arum lily and calla lily petiole culture were able to form callus on the MS medium without growth regulators where arum lily petiole segments formed callus at the frequency of $16.3 \%$, and calla lily at $24.3 \%$.

To induce the callus genesis of the Zantedeschia Spreng. in petiole culture, scientists use lower quantities of macro and micro salts and MS nutrient medium is supplemented with combinations of growth regulators. Callus formation rate of $53.3 \%$ was obtained when $1.0 \mathrm{mg} \mathrm{l}^{-1}$ 2,4-D + $1.0 \mathrm{mg} \mathrm{l}^{-1}$ BAP combination was added to the medium. Sakpere and Adebona (2007) investigated petiole isolated tissue culture of Caladium (these plants belong to the same family). It was found that under the influence of KIN, explants formed callus at the rate of $33 \%$.

In our research it was determined that callus formation frequency of calla lily petiole segment culture in the medium with $0.25 \mathrm{mg} \mathrm{l}^{-1}$ IAA $+2.0 \mathrm{mg} \mathrm{l}^{-1}$ BAP was $78.9 \%$. Increasing the concentration of IAA in the nutrient medium increased the callus formation rate. Petiole explants formed callus in $100 \%$ frequency in the medium supplemented with $1.0 \mathrm{mg} \mathrm{l}^{-1}$ and $2.0 \mathrm{mg} \mathrm{l}^{-1} \mathrm{IAA}$.

\section{CONCLUSIONS}

The calla lily manifested a higher power of dedifferentiation than the arum lily. To induce callus genesis on somatic tissues of the arum lily, the most suitable nutrient medium must be supplemented with $0.5 \mathrm{mg} 1^{-1} \mathrm{IAA}+2.0 \mathrm{mg} 1^{-1}$ BAP (leaf explants), $2.0 \mathrm{mg}^{-1} \mathrm{IAA}+2.0 \mathrm{mg} 1^{-1}$ 
BAP (spathe explants), and $1.0 \mathrm{mg} \mathrm{1^{-1 }} \mathrm{IAA}+$ $2.0 \mathrm{mg}^{-1}$ BAP (petiole explants). Somatic tissues of the calla lily formed callus most intensively in the medium supplemented with $1.0 \mathrm{mg}^{-1} \mathrm{IBA}+2.0 \mathrm{mg}^{-1} \mathrm{BAP}$ (leaf explants), $1.0 \mathrm{mg}^{-1} \mathrm{IAA}+2.0 \mathrm{mg}^{-1} \mathrm{BAP}$ (petiole explants), and $2.0 \mathrm{mg} \mathrm{l}^{-1} \mathrm{KIN}$ (spathe explants). Petiole segments formed callus more intensively than isolated tissues of leaves and spathe.

Received 16 June 2017 Accepted 4 December 2017

\section{References}

1. Budiarto K. Micro propagation of several potted Anthurium accessions using spathe explants. J Nature Indonesia. 2008; 11: 59-63.

2. Chang HS, Charkabarty D, Hahn EJ, Paek KY. Micropropagation of calla lily (Zantedeschia albomaculata) via in vitro shoot tip proliferation. In Vitro Cell Dev Biol-Pl. 2003; 39(2): 129-34.

3. Chen JJ, Liu MC, Ho YH. Size of in vitro plantlets affects subsequent tuber production of acclimated calla lily. Hortic Sci. 2000; 35: 290-2.

4. Cohen D. Micropropagation of Zantedeschia hybrids. Comb Proc Intl Plant Prop Soc. 1981; 31: 312-6.

5. Coleman J, Evans D, Kearns A. Plant Cell Culture. Garland Science; 2003. 208 p.

6. Corr BE, Widmer RE. Rhizome storage increases growth of Zantedeschia elliottiana and Z. rehmannii. Hortic Sci. 1988; 23: 1001-2.

7. Corr BE, Widmer RE. Gibberellic acid increases flower number in Zantedeschia elliottiana and Z. rehmannii. Hortic Sci. 1987; 22: 605-7.

8. Corr BE, Widmer RE. Paclobutrazol, gibberellic acid and rhizome size affect growth and flowering of Zantedeschia. Hortic Sci. 1991; 26: $133-5$.

9. Corr BE. Zantedeschia research in the United States: past, present and future. Acta Hortic. 1993; 337: 177-89.
10. D'arth SM, Simpson SI, Seelye JF, Jameson PE. Bushiness and cytokinin sensitivity in micropropagated Zantedeschia. Plant Cell Tiss Org Cult. 2002; 70(1): 113-8.

11. Duquenne B, Eeckhaut T, Werbrouck S, Van Huylenbroeck J. In vitro somatic embryogenesis and plant regeneration in Zantedeschia hybrids. Plant Cell Tiss Org Cult. 2006; 87(3): 329-31.

12. Ebrahim M. Comparison, determination and optimizing the conditions required for rhizome and shoot formation, and flowering of in vitro cultured calla explants. Scientia Horticulturae. 2004; 101(3): 305-13.

13. Gong X, Qu F, You C, Sun W, Wang M. Establishment of callus induction system from leaves in Zantedeschia. J Yantai University (Natural Science and Engineering Edition). 2008; 3: 221-5.

14. Yip MK, Hsiang-En H, Mang-Jye G, ShihHua C, Yuh-Chih T, Chin-I L, Teng-Yung F. Production of soft rot resistant calla lily by expressing a ferredoxin-like protein gene (pflp) in transgenic plants. Plant Cell Rep. 2007; 26(4): 449-57.

15. Khanam N, Khoo C, Khan A. G. Effects of cytokinin/auxin combination on organogenesis, shoot regeneration and tropane alkaloid production in Duboisia myoporoides. Plant Cell Tiss Org Cult. 2000; 62: 125-33.

16. Kuehny JS. Calla history and culture. HortTechnology. 2000; 10: 267-74.

17. Letty C. The genus Zantedeschia. Bothalia. 1973; 11(1-2): 5-26.

18. Makunga NP, Jager AK, van Staden J. An improved system for the in vitro regeneration of Thapsia garganica via direct organogenesis - influence of auxins and cytokinins. Plant Cell Tiss Org Cult. 2005; 82: 271-80.

19. Murashige T, Skoog F. A revised medium for rapid growth and bioassays with tobacco tissue cultures. Physiol Plant. 1962; 15: 473-97.

20. Naor V, Kigel J, Ziv M. Hormonal control of inflorescence development in plantlets of calla 
lily (Zantedeschia spp.) grown in vitro. Plant Growth Regul. 2004; 42(1): 7-14.

21. Plummer JA, Welsh TE, Armitage AM. Stages of flower development and post production longevity of potted Zantedeschia aethiopica 'Childsiana'. HortScience. 1990; 25: 675-6.

22. Robinson KEP, Firoozabady E. Transformation of floricultural crops. Sci Hortic. 1993; 55: 83-99.

23. Ruiz SG, Rosa ME, Flores OCE. Zantedeschia aethiopica propagation by tissue culture. J Agr Univ Puerto Rico. 1996; 80(3): 193-4.

24. Sakakibara H. Cytokinins: activity, biosynthesis, and translocation. Annu Rev Plant Biol. 2006; 57: 431-9.

25. Sakpere AMA, Adebona AC. Tissue culture derived plantlet variation in Caladium humbolditi Schott. J Sci Technol. 2007; 7(1): 28-34.

26. Tarakanovas P, Raudonius S. Agronominių tyrimų duomenų statistinè analizé taikant kompiuterines programas AVONA, STAT, SPLIT-PLOT iš paketo SELEKCIJA ir IRRISTAT. Akademija (Kèdainių r.); 2003. 57 p. Lithuanian.

27. Thorpe T. History of plant tissue culture. J Mol Microbial Biotechnol. 2007; 37: 169-80.

28. Tjia B. Zantedeschia. In: AH Halevy (ed.). The CRC handbook of flowering, vol. VI. Boca Raton: CRC Press; 1989. p. 697-702.

29. Werner T, Motyka V, Laucou V, Smets R, Van Onckelen H, Schmulling T. Cytokinin - deficient transgenic Arabidopsis plants show multiple developmental alterations indicatingnopposite functions of cytokinins in the regulation of shoot and root meristem activity. Plant Cell. 2003; 15: 2532-50.

30. Zheng Z. Study on establishment and optimization of tissue culture in rapid propagation system of Zantedeschia Aethiopica and Zantedeschia Hybrid. Globe thesis [Internet]. 2010 Sept [cited 2017 Mar 6]. Available from: http://www.globethesis. com/?t=2143360278452869
Vaida Jonytienė, Ramunė Masienė, Natalija Burbulis, Aušra Blinstrubienẻ

\section{ZANTEDESCHIA SPRENG. DEDIFERENCIA- CIJĄ IN VITRO LEMIANTYS VEIKSNIAI}

\section{Santrauka}

Zantedeschia Spreng. yra viena iš ekonomiškai svarbiụ dekoratyviụ augalų rūšiuc. Dekoratyvių augalų pramonejje didelę reikšmę turi estetinių savybiu potencialo ir naujų dekoratyvių savybių kūrimas. Tyrimo metu buvo ivvertintas augimo reguliatoriu bei eksplanto tipo poveikis Zantedeschia aethiopica ir Zantedeschia elliottiana dediferenciacijos indukcijai. Tyrimai atlikti 2016-2017 m. Aleksandro Stulginskio universiteto Agronomijos fakulteto Biologijos ir augalų biotechnologijos institute bei Jungtinių tyrimų centro Agrobiotechnologijos laboratorijoje. Izoliuoti kalijos eksplantai - lapai, papeddlapiai ir lapkočiai - auginti Murashige ir Skoog (MS) bazinèje maitinamojoje terpèje su skirtingais augimo reguliatoriais - indolil-3-acto rūgštimi (IAR), indolil-3-sviesto rūgštimi (ISR) ir 6-benzilamino purinu (BAP), kurie buvo papildyti $30 \mathrm{~g}^{\mathrm{l}^{-1}}$ sacharozès, $8 \mathrm{~g} \mathrm{l}^{-1}$ agaro.

Maitinamojoje terpëje be augimo reguliatorių izoliuoti kalijos lapų ir papedlapių segmentai kaliaus neformavo, o izoliuoti lapkočiai kalių formavo $-16,3 \%$ (Zantedeschia aethiopica) ir 24,3\% (Zantedeschia elliottianna). Kaliaus formavimosi intensyvumas priklausè nuo augimo reguliatorių derinio maitinamojoje terpeje ir pasirinkto eksplanto tipo. Tyrimo rezultatai rodo, kad izoliuoti lapkočiai intensyviausiai kalių formavo BAP + IAR papildytose maitinamosiose terpèse, o papédlapiai - terpèse su BAP + ISR. Iš tirtų kalijos eksplantų izoliuoti lapkočių audiniai pasižymėjo didžiausiu dediferenciacijos dažniu. Tyrimo rezultatais nustatyta, kad dviejų rūšių - Zantedeschia aethiopica ir Zantedeschia elliottiana - kalijos somatinai audiniai yra tinkama medžiaga tobulinant šių augalų dekoratyvumą.

Raktažodžiai: Zantedeschia Spreng., eksplantas, kaliaus indukcija, augimo reguliatoriai 